\title{
Linking Bone Health and Psychological/Mental Health
}

\author{
Saima Khan* \\ Malir University of Science and Technology, Pakistan
}

Submission: July 05, 2021; Published: July 13, 2021

*Corresponding author: Saima khan, Malir University of Science and Technology, Pakistan

\begin{abstract}
Ethnocentrism has been the most constant social problem and as such, living together in a harmonious society with different ethnic backgrounds, culture, language, and religion has not been easy for society. The objective of this study was be to explore the causes, impacts, and mediums of ethnocentrism on societies in selected zones of South Nation Nationalities and Peoples Region. The study used a combination of purposive, stratified and simple random sampling techniques to select 3 zones, 343 respondents to represent the total population as a sample. Both quantitative and qualitative data were collected using two separate instruments, questionnaire and focus group discussion. Data was analyzed and presented in descriptive statistics and inferential statistics. Frequency, percentage, and mean were used to analyze quantitative data about causes, effects, and mediums of ethnocentrism. Independent sample t-test was used to analyze sex difference between male and female respondents in their ethnocentric attitudes. One way ANOVA was employed to examine the differences in demographic variables (age, experience, educational level, and marital status) in the scores on respondents' ethnocentric attitudes. From the analysis, the following findings were identified. Political factors are the most serious causes of ethnocentric attitudes. The leading effects of ethnocentrism were national agenda narrowed and replaced by ethnic agenda, property loss, and making false assumptions about others. Ethnocentric attitudes were enforced by wrong use of agenda of ethnic parties, ethnic federalism, social media, ethnic literatures, and ethnic based sport clubs. Based on the findings of the result, the present study provided recommendations for the concerned stake holders to reduce ethnocentrism.
\end{abstract}

Keywords: Ethnocentrism; Causes of ethnocentrism; Effects of ethnocentrism; Mediums of ethnocentrism

\section{Editorial}

We all go through stressful situations in life, and this can be on a regular basis, but most of us may not comprehend how stress and bone health are inextricably linked. Stress, whether workrelated, family-related, environmental, physical, or emotional, throws our bodies off balance and can even induce calcium loss in bones.

Physical stress (for example through falls, continuous hard exercise, and inflammatory diets) can contribute to bone loss. And mental stress can have the same effect. A person's mental state can wear down their bones as demonstrated in a new study by JiaSheng and colleagues that suggests that high stress levels affect bone health, and may even lead to osteoporosis and an increased risk of fracture [1].

Our systems release calcium from our bones and teeth to assist restore balance, similar to how antacids neutralise stomach acid. Calcium, being alkaline, helps restore our bodies' $\mathrm{Ph}$ balance by neutralising the acidifying effects of cortisol [2]. Each time we do this, our calcium stores in our bones are further depleted. It is assumed that the simple answer is to eat more dairy and everything will be $\mathrm{OK}$, but it's not that straightforward. When stress becomes chronic, diet alone is unable to replenish calcium depletion quickly enough, causing calcium to repeatedly being leached out from our bones, potentially leading to more porous and brittle bones, and consequently osteoporosis [3].

Brittle and fragile bones may decrease mobility, increase the risks of injury, and physical pain, and with this, one may feel hopeless, or this may add to their worries. Yet, when we are stressed and worried, our bodies create cortisol, a "stress hormone" that can disrupt normal biological functions. Adrenal glands create cortisol, which is a stress hormone. While, cortisol is produced naturally in the body as a result of many "positive" activities such as exercise and waking up in the morning, it is also produced as a result of mental/psychological pressures. 
Cortisol, in fact, aids in the activation of the body's "fight-or-flight" response in high-stress situations. While this isn't necessarily a bad thing, persistent stress causes the body to become inflamed and inflammation is a catalyst for many compounding physical problems and the worsening of symptoms in persons already suffering from bone density concerns. Increased cortisol levels accompany increased inflammation, which can wreak havoc on bone health [4].

Cortisol, for starters, promotes bone resorption. That is, bone density declines as the body produces more osteoclasts, or boneresorbing cells as a response to consistently high cortisol levels. In the same time, high cortisol levels prevent osteoblasts, or the bone-building cells, from forming new bone. In addition, cortisol prevents calcium from entering bones. In turn, the body isn't as efficient at absorbing calcium, and without this building block, bone density is expected to further deteriorate over time. As a result, bone growth is slowed, resulting in compounding effects on already weak bones [5]. The higher the stress, the more harm this does to bones. To reduce the negative consequences of stress, there are some strategies that make a significant difference. (They're useful for a lot more than simply bone health.).

\section{Ways to Relief from Stress}

\section{Exercise}

You can work out! Exercise, especially weight-bearing exercise, is an excellent stress reducer and it is known to reinforce bones. Do what you're passionate about. Almost any type of exercise or activity can improve your fitness while also lowering your stress levels. The most important thing is to choose something you enjoy doing. Walking, dancing, stair climbing bicycling, gardening, yoga, weightlifting, jogging, swimming and tai chi are just a few examples [6].

\section{Meditation}

Mindfulness meditation involves increased awareness of the present moment. With practice, it can be utilized anywhere and can bring lasting stress relief benefits. Simple meditation technique can be learned quickly and is considered by many as a perfect solution for relieving stress. During meditation, posture remains important, and when meditation is combined with breathing and stretching/movement, we get yoga, which is known to reinforce bones, circulatory and muscular structures [7].

\section{Healthy eating}

Anxiety and worry produce heightened oxidative stress, which means that cells are oxidised by a large number of free radicals. Antioxidants found in a healthy diet are crucial for a normal immune response and to maintain your health, since they combat free radicals (and thus oxidative stress) in the body. Some of antioxidants that can easily be incorporated in one's diet includes berries like cranberries and blueberries, nuts like almonds, walnuts and pecans, spices like cinnamon, turmeric and oregano, etc. Moreover, a variety of other foods like dark chocolate, artichokes, and fish oil are also high in antioxidants [8].

\section{Laughing}

This is a rather self-explanatory one. The hormone serotonin, a neurotransmitter that can improve your mood, is produced by a pleasant bout of laughter. Endorphins, which provide a "natural high," flow into your brain, allowing you to relax. Tension is released during and immediately following a good laugh, humorous encounter, or fun? So, under pressure, joking around can be beneficial. A little laughter can help important stress build up [9].

\section{Sleep}

This one is also basic, but shouldn't be overlooked. The body demands sleep, and even if one can "function" on 3-4 hours of sleep per night, this still deprives the body of vital rest. A detailed study conducted by a diverse group of medical professionals was issued by the National Sleep Foundation. Adults up to 64 years old should get 7-9 hours of good sleep per night, according to their findings. Those aged 65 and up require 7-8 hours of sleep per night. Sleep deprivation may increase stress levels, and therefore, nefariously affect bone health. And when falling asleep is difficult, four natural sleep aids can assist in getting a better night's sleep [10]:

a) Aromatherapy - Essential oils have been shown in studies to help reduce tension and improve relaxation, resulting in a more peaceful night's sleep.

b) Dietary choices - Certain meals, such as sour cherry juice, milk, and brown rice, can really help people sleep better.

c) Sleep hygiene - Sleep hygiene is shutting off all bright lights (including electronic devices), regulating the temperature in the bedroom, and, if desired, employing a white noise machine to create the ideal sleeping environment.

d) Calcium - Calcium has been shown in studies to assist in regulating the sleep cycle. If calcium levels are low, which is often linked to poor bone health, one may wake up more easily and experience sporadic sleep cycles. So, natural calcium supplement could help.

Try one or more of these natural stress relieving techniques, if you, your ageing partner, or a loved one feels stressed especially when also experiencing bone deterioration. Remember that mental tension isn't just bad for our mood. It can also have compounding negative impacts on bone health, especially as we age, and among the elderly.

\section{References}

1. Ng JS, Chin KY (2021) Potential mechanisms linking psychological stress to bone health. International Journal of Medical Sciences, 18(3): 604-614. 
2. Horowitz S (2009) Acid-Base Balance, Health, and Diet. Alternative and Complimentary Therapies 15(6): 292-297.

3. Azuma K, Adachi Y, Hayashi H, Kubo KY (2015) Chronic psychological stress as a risk factor of osteoporosis. J UOEH 37(4): 245-253.

4. Johnson AR, Justin Milner J, Makowski L (2012) The inflammation highway: metabolism accelerates inflammatory traffic in obesity. Immunological reviews 249(1): 218-238.

5. Furan PM, Ten Have T, Cary M, Zemel B, Wehrli F, et al. (2005) The role of stress-induced cortisol in the relationship between depression and decreased bone mineral density. Biol psychiatry 57(8): 911-917.

6. Moreira VMPS, da Silva Soares F, Hattori WT, Dionisio VC (2021) A comparison of the efficacy of non weight-bearing and weight-bearing exercise programmes on function and pain pressure thresholds in knee osteoarthritis: a randomised study. European Journal of Physiotherapy 23(3): 171-178.

7. Balaji Deekshitulu PV (2017) Meditation and Positive Mental Health. J Psychiatry Cogn Behav 2: 108.

8. Lobo V, Patil APA, Chandra N (2010) Free radicals, anti oxidants and functional foods: Impact on human health. Pharmacogn Rev 4(8): 118.

9. Penson RT, Partridge RA, Rudd P, Seiden MV, Nelson JE, et al. (2005) Laughter: the best medicine? The oncologist 10(8): 651-660.

10. Farrell PA (2019) Sleep, Insomnia, Stress: What you don't know can hurt you. Patricia A Farrell PhD, LLC.

\section{Your next submission with Juniper Publishers will reach you the below assets}

- Quality Editorial service

- Swift Peer Review

- Reprints availability

- E-prints Service

- Manuscript Podcast for convenient understanding

- Global attainment for your research

- Manuscript accessibility in different formats

( Pdf, E-pub, Full Text, Audio)

- Unceasing customer service

Track the below URL for one-step submission https://juniperpublishers.com/online-submission.php 